\title{
Of creatures great and small: the advantages of farm animal models in immunology research
}

\section{Amanda J. Gibson', Tracey J. Coffey ${ }^{2}$ and Dirk Werling ${ }^{1 *}$ \\ 1 Department of Pathology and Infectious Diseases, Royal Veterinary College, London, UK \\ 2 School of Veterinary Medicine and Sciences, University of Nottingham, Sutton Bonington, UK \\ ${ }^{*}$ Correspondence: dwerling@rvc.ac.uk}

\section{Edited by:}

Virgil Schijns, Wageningen University, Netherlands

Reviewed by:

Virgil Schijns, Wageningen University, Netherlands

In recent decades the inappropriate use of antibiotics in farm animals, either as growth enhancers or for treatment of infectious diseases, has resulted both in higher concentrations of antibiotic residues in meat destined for the human food chain and in an increasing prevalence of antibiotic-resistant bacteria (Carlet et al., 2012). Increased public concerns regarding their potential impact on human health may result in a reduction or cessation in the use of antibiotics in farm animals (Veterinary Record, 2011,2012). Thus, alternative treatments for the control of infectious diseases in farm animals need to be identified as a research priority. In achieving this goal, the physiological relevance of an animal model to the intended target population becomes a key factor. The majority of models currently used for pharmaceutical research are murine and it is possible that potentially valuable therapeutics are discounted on the basis of lack of responses generated in this system, as shown very recently for sepsis (Seok et al., 2013). Several non-rodent species, such as cattle, pigs, and chicken, are both valuable models for infectious diseases in humans (Hein and Griebel, 2003; Visscher and Goddard, 2011; Waters et al., 2011; Costa et al., 2012; Meurens et al., 2012) and important clinical targets in their own right. Effective vaccines have been developed for many acute viral and bacterial infections, whereas for others, like tuberculosis (TB), there is still a need for reliable vaccines. Pathology seen in the murine models of TB currently used is very different to the pathology seen in humans (Gupta and Katoch, 2009), whereas the bovine and human diseases share many similarities (Waters et al., 2011). For such diseases it is crucial that we use natural disease-models, with the appropriate pathogen in the most appropriate host, to examine the host-pathogen interactions that occur in outbred populations. A fundamental point in the development of new and improved intervention strategies is the understanding of host differences in the innate immune response, which primes the subsequent adaptive immune response. Although the innate immune system has been largely conserved during evolution, marked variations and diversity exist between different mammalian species within PatternRecognition-Receptor (PRR) structure (Jungi et al., 2011). These differences are based on evolutionary pressure within the innate immune system, potentially reflecting the specific threats encountered by each species (Zhang et al., 2010). This selective pressure appears to be absent in the available murine sequences (Werling et al., 2009). The similarity between human and farm animal PRR (Jungi et al., 2011) is further supported by their similar response to ligands (Kapetanovic et al., 2012), in contrast to murine PRR (Hajjar et al., 2002; Grabiec et al., 2004; Farhat et al., 2010). Since recognition by PRR is associated with adaptive immunity by providing optimal immunostimulation, learning more about these key molecules in farm animals might inform us about their adjuvant effect in vaccines for use in these animals as well as humans. Given the size and blood volumes of farm animals, there are also greater opportunities to repeatedly access to different cell types - an asset which would facilitate the assessment of cell specific effects of such immunomodulatory agents on autologous cells (Hein and Griebel, 2003). Farm animal models do have their disadvantages such as dedicated housing, biosecurity, and the confinement of infected animals. However, it is misleading to rely on murine models to fill the gaps in our knowledge of disease-pathogenesis, and choosing a research model should be more than just a matter of convenience and convention (Bolker, 2012).

However, in addition to their potential use as models for human diseases, research in farm-animals models have a "right-ontheir-own," taken the predicted increase in food supply necessary by $70 \%$ to support an ever-increasing global population as well as the occurrence of new emerging diseases, such as Schmallenberg virus into account. These challenges can be faced and overcome by an increased readiness of farm animal research centers to apply their models in novel ways, a willingness of the medical profession to accept more suitable diseasemodels, and a willingness of funding agencies and companies to invest in this type of research partnership.

\section{ACKNOWLEDGMENT}

We thank D. McKeever (RVC) for helpful discussions and revisions. Amanda J. Gibson, Tracey J. Coffey and Dirk Werling are funded through the BBSRC, especially the "Combating Endemic Diseases of Farmed Animals for Sustainability (CEDFAS)" initiative, DEFRA, Wellcome Trust and industrial grants. This manuscript represents number PID_00272 of the RVC.

\section{REFERENCES}

Bolker, J. (2012). Model organisms: there's more to life than rats and flies. Nature 491, 31-33. doi: 10.1038/491031a

Carlet, J., Jarlier, V., Harbarth, S., Voss, A., Goossens, H., and Pittet, D. (2012). Ready for a world without antibiotics? The Pensieres Antibiotic Resistance Call to Action. Antimicrob. Resist. Infect. Control 1, 11. doi: 10.1186/2047-2994-1-11

Costa, L. F., Paixao, T. A., Tsolis, R. M., Baumler, A. J., and Santos, R. L. (2012). Salmonellosis in cattle: 
advantages of being an experimental model. Res. Vet. Sci. 93, 1-6. doi: 10.1016/j.rvsc.2012.03.002

Farhat, K., Riekenberg, S., Jung, G., Wiesmuller, K. H., Jungi, T. W., and Ulmer, A. J. (2010). Identification of full length bovine TLR1 and functional characterization of lipopeptide recognition by bovine TLR2/1 heterodimer. Vet. Res. 41,34. doi: 10.1051/vetres/2010006

Grabiec, A., Meng, G., Fichte, S., Bessler, W., Wagner, H., and Kirschning, C. J. (2004). Human but not murine toll-like receptor 2 discriminates between tri-palmitoylated and tri-lauroylated peptides. J. Biol. Chem. 279, 48004-48012. doi: 10.1074/jbc.M405311200

Gupta, U.D., and Katoch, V.M. (2009). Animal models of tuberculosis for vaccine development. Indian J. Med. Res. 129, 11-18.

Hajjar, A. M., Ernst, R. K., Tsai, J. H., Wilson, C. B., and Miller, S. I. (2002). Human Toll-like receptor 4 recognizes host-specific LPS modifications. Nat. Immunol. 3, 354-359. doi: 10.1038/ni777

Hein, W. R., and Griebel, P. J. (2003). A road less travelled: large animal models in immunological research. Nat. Rev. Immunol. 3, 79-84. doi: 10.1038/nri977

Jungi, T. W., Farhat, K., Burgener, I. A., and Werling, D. (2011). Toll-like receptors in domestic animals. Cell Tissue Res. 343, 107-120. doi: 10.1007/ s00441-010-1047-8
Kapetanovic, R., Fairbairn, L., Beraldi, D., Sester, D. P. Archibald, A. L., Tuggle, C. K., et al. (2012). Pig bone marrow-derived macrophages resemble human macrophages in their response to bacterial lipopolysaccharide. J. Immunol. 188, 3382-3394. doi: 10.4049/ jimmunol.1102649

Meurens, F., Summerfield, A., Nauwynck, H., Saif, L., and Gerdts, V. (2012). The pig: a model for human infectious diseases. Trends Microbiol. 20, 50-57. doi: 10.1016/j.tim.2011.11.002

Seok, J., Warren, H. S., Cuenca, A. G., Mindrinos, M. N., Baker, H. V., Xu, W., et al. (2013). Genomic responses in mouse models poorly mimic human inflammatory diseases. Proc. Natl. Acad. Sci. U.S.A. 110, 3507-3512. doi: 10.1073/pnas.1222878110

Veterinary Record. (2011). Call to phase out prophylactic use of antimicrobials in livestock. Vet. Rec. 169, 479-480. doi: 10.1136/vr.d7090

Veterinary Record. (2012). US FDA told to stop certain antibiotics being used as growth promoters. Vet. Rec. 170, 348. doi: 10.1136/vr.e2472

Visscher, P. M., and Goddard, M. E. (2011). Cattle gain stature. Nat. Genet. 43, 397-398. doi: 10.1038/ng.819

Waters, W. R., Palmer, M. V., Thacker, T. C., Davis, W. C., Sreevatsan, S., Coussens, P., et al. (2011). Tuberculosis immunity: opportunities from studies with cattle. Clin. Dev. Immunol. 2011, 768542. doi: $10.1155 / 2011 / 768542$

Werling, D., Jann, O. C., Offord, V., Glass, E. J., and Coffey, T. J. (2009). Variation matters: TLR structure and species-specific pathogen recognition. Trends Immunol. 30, 124-130. doi: 10.1016/j.it.2008.12.001

Zhang, Q.,Zmasek, C. M., and Godzik,A. (2010). Domain architecture evolution of pattern-recognition receptors. Immunogenetics 62, 263-272. doi: 10.1007/ s00251-010-0428-1

Received: 09 May 2013; accepted: 11 May 2013; published online: 27 May 2013.

Citation: Gibson AJ, Coffey TJ and Werling D (2013) Of creatures great and small: the advantages of farm animal models in immunology research. Front. Immunol. 4:124. doi: 10.3389/fimmu.2013.00124

This article was submitted to Frontiers in Immunotherapies and Vaccines, a specialty of Frontiers in Immunology.

Copyright (C) 2013 Gibson, Coffey and Werling. This is an open-access article distributed under the terms of the Creative Commons Attribution License, which permits use, distribution and reproduction in other forums, provided the original authors and source are credited and subject to any copyright notices concerning any thirdparty graphics etc. 